\title{
Profil Eritrosit Ikan Mas (Cyprinus carpio L) yang Diberi Pakan Mengandung Vaksin Aeromonas hydrophila
}

\author{
Erythrocyte Profile of Cyprinus carpio Feed Contains Aeromonas hydrophila \\ Vaccine
}

\author{
Isna Sudirman $^{1 *}$, Henni Syawal ${ }^{1}$, Iesje Lukistyowati ${ }^{1}$ \\ ${ }^{1}$ Jurusan Budidaya Perairan, Fakultas Perikanan dan Kelautan, Universitas Riau \\ email:isnasudirman4@gmail.com
}

(Received: 08 Juni 2021; Accepted: 30 Juni 2021)

\begin{abstract}
ABSTRAK
Ikan mas (Cyprinus carpio) merupakan jenis ikan air tawar yang banyak dikonsumsi. Salah satu penyakit yang biasa menyerang ikan mas adalah Motile Aeromonos Septiceamia yang disebabkan oleh Aeromonas hydrophila. Vaksinasi adalah pemberian vaksin yang tujuan utnuk meningkatkan kekebalan ikan terhadap bakteri A.hydrophila. Penelitian ini bertujuan untuk menganalisis profil darah merah ikan mas yang diberi vaksin $A$. hydrophila pada pakan dengan dosis yang berbeda, dan mendapatkan dosis vaksin A. hydrophila terbaik ditambahkan ke pakan. Metode yang digunakan dalam penelitian ini adalah metode eksperimen dengan menerapkan Rancangan Acak Lengkap (RAL) satu faktor dengan empat taraf perlakuan, yaitu adalah Kn (Pemberian pakan tanpa diberi Vaksin A.hydrophila), $\mathrm{P}_{1}$ (Pemberian Vaksin A.hydrophila dengan Dosis $3 \mathrm{~mL} / \mathrm{Kg}$ pakan), $\mathrm{P}_{2}$ (4 $\mathrm{mL} / \mathrm{Kg}$ pakan), dan $\mathrm{P}_{3}(5 \mathrm{~mL} / \mathrm{Kg}$ pakan $)$. Ikan dipelihara dalam keramba berukuran $1 \times 1 \times 1$ m sebanyak 12 unit. Ikan yang digunakan berukuran 8-10 cm, dipelihara selama 30 hari. Hasil penelitian menunjukkan bahwa ada pengaruh pemberian A.hydrophila pada pakan terhadap profil darah merah ikan mas yang dipelihara di keramba $(\mathrm{P}<0,05)$. Dosis terbaik pemberian vaksin A.hydrophila pada pakan yaitu $5 \mathrm{~mL} / \mathrm{kg}$ pakan (P3), dilihat dari gambaran darah merah seperti rata-rata total eritrosit $2,12 \times 10^{6} \mathrm{sel} / \mathrm{mm}^{3}$, hemoglobin $8,67 \mathrm{~g} / \mathrm{dL}$, kadar hematokrit $34,33 \%$, tingkat perlindungan relatif $66,67 \%$, dan kelulushidupan $97,33 \%$.
\end{abstract}

Kata Kunci: Cyprinus carpio, Vaksin, Motile Aeromonas Septicaemia, Pakan, Hematologis

\begin{abstract}
Carp (Cyprinus carpio) is a type of freshwater fish that is widely consumed. One of the diseases that commonly infection carp is Motile Aeromonos Septicemia which is caused by Aeromonas hydrophila. Vaccination is the giving of vaccines with the aim of increasing fish immunity against $A$. hydrophila bacteria. The aim of the study was to analyze the erythrocyte profile of carp given the A. hydrophila vaccine in different doses of feed, and to get the best dose of A. hydrophila vaccine added to the feed. The method used in this study was an experimental method by applying a one-factor completely randomized design (CRD) with four treatment levels, namely Kn (Feeding without HydroVac Vaccine), P1 (Giving A. hydrophila Vaccine with a Dose of $3 \mathrm{~mL} / \mathrm{Kg}$ of feed), P2 (4 mL / Kg of feed), and P3 (5 mL / Kg of feed). Fish are kept in cages measuring $1 \times 1 \times 1 \mathrm{~m}$ as many as 12 units. The fish used are an average length of $9-10 \mathrm{~cm}$, reared for 30 days. The results showed that there was an effect of giving A. hydrophila to the feed on the erythrocyte of carp reared in cages $(\mathrm{P}<0.05)$. The best dose of A.hydrophila vaccine in feed is 5 $\mathrm{mL} / \mathrm{kg}$ of feed (P3), seen from the erythrocyte profile such as an average total erythrocytes $2.12 \times$ $10^{6}$ cells $/ \mathrm{mm}^{3}$, hemoglobin $8.67 \mathrm{~g} / \mathrm{dL}$, hematocrit levels $34.33 \%$, the relative percent survival is $66.67 \%$, and the survival rate is $97.33 \%$
\end{abstract}

Keyword: Cyprinus carpio, Vaccine, Motile Aeromonas Septicaemia, oral, hematologis 


\section{Pendahuluan}

Ikan mas (Cyprinus carpio) merupakan jenis ikan air tawar yang banyak dikonsumsi. Budidaya ikan mas di Indonesia banyak dilakukan, baik budidaya pembesaran di kolam, sawah, waduk, maupun dalam keramba di perairan umum. Ikan mas mempunyai sifat unggul diantaranya, adalah mudah dalam pemeliharaan, pertumbuhannya cepat dan mempunyai nilai ekonomis penting, sehingga banyak dibudidayakan. Produksi ikan mas pada tahun 2014 mencapai 28,22 juta ton dan mengalami peningkatan lebih dari 4,1 juta ton pada tahun 2017 (FAO, 2019).

Jenis ikan ini banyak disukai oleh konsumen dan permintaannya terus meningkat. Berbagai sistem budidaya telah diterapkan dan terus berkembang untuk memperoleh produksi ikan mas yang maksimal. Salah satunya dengan menerapkan sistem budidaya intensif yang dilakukan dengan padat tebar tinggi dan penggunaan pakan buatan, serta teknologi yang modern. Penyakit yang sering menyerang ikan mas salah satunya disebabkan oleh bakteri Aeromonas hydrophila (Maryani dan Rosita, 2006). Bakteri A. hydrophila adalah bakteri Gram negatif yang bersifat oportunistik dan dapat menginfeksi banyak spesies ikan (Citarasu et al., 2011; Zhang et al., 2014), sehingga menimbulkan wabah penyakit dan dapat menyebabkan kematian pada ikan hingga $80 \%-100 \%$ dalam waktu 1 minggu (Mulia, 2012).

Salah satu alternatif dalam pencegahan penyakit bakterial pada ikan adalah menggunakan vaksin A. hydrophila. Vaksinasi memberikan solusi yang efektif namun murah untuk memerangi resiko penyakit dalam budidaya ikan. Aplikasi vaksinasi yang tepat untuk mencegah penyakit bakteri memberikan solusi terhadap efek bahaya dari aplikasi antibiotik (Mohd-Aris et al., 2019).

Salah satu jenis vaksin yang dapat digunakan dalam pencegahan penyakit MAS adalah HydroVac. Vaksin HydroVac telah dikembangkan sejak tahun 2009 di Balai Penelitian dan Pengembangan Budidaya Air Tawar (BPPBAT), yang memiliki kemampuannya untuk menginduksi respons kebal spesifik yang dapat bereaksi silang (cross reactivity) terhadap beberapa strain bakteri A. hydrophila (Taukhid et al., 2015).
Vaksin HydroVac telah diaplikasikan pada beberapa jenis ikan, diantaranya adalah gurami (Osphronemus gouramy) (Mulia, 2007), lele (Clarias gariepinus) (Andriyanto dan Sugiani, 2015; Sumiati et al., 2019), Patin (Pangasionodon hypophthalmus) (Lusiastuti dan Hadie, 2010; Sinaga et al., 2019; Mailani et al., 2020). Menurut Taukhid et al. (2016) pencegahan penyakit pada budidaya ikan air tawar melalui penggunaan vaksin HydroVac dapat menurunkan tingkat kematian ikan akibat penyakit MAS berkisar 30-40\% dibandingkan dengan tanpa aplikasi vaksin yang mencapai $60-70 \%$.

Berdasarkan uraian di atas peneliti tertarik untuk melakukan penelitian tentang profil eritrosit ikan mas yang diberi pakan mengandung vaksin HydroVac dan dipelihara dalam keramba. Tujuan penelitian adalah untuk menganalisis profil darah merah ikan mas yang diberi vaksin HydroVac pada pakan dengan dosis yang berbeda, dan mendapatkan dosis vaksin HydroVac terbaik ditambahkan ke pakan

\section{Metode Penelitian}

\subsection{Waktu dan Tempat}

Penelitian ini dilaksanakan pada bulan September sampai November 2020 di Laboratorium Parasit dan Penyakit Ikan Fakultas Perikanan dan Kelautan, Universitas Riau. Pemeliharaan ikan dilakukan di Waduk Fakultas Perikanan dan Kelautan, Universitas Riau.

\subsection{Metode Penelitian}

Metode yang digunakan dalam penelitian ini adalah metode eksperimen dengan menerapkan Rancangan Acak Lengkap (RAL) satu faktor dengan empat taraf perlakuan, untuk mengurangi tingkat kekeliruan maka dilakukan ulangan sebanyak tiga kali sehingga diperlukan 12 unit percobaan. Dosis perlakuan pada penelitian ini sesuai dengan Indrawati dan Supriyadi (2009), adapun dosis vaksin HydroVac yang digunakan di dalam pakan adalah sebagai berikut :

$\begin{aligned} \mathrm{Kn}= & \begin{array}{l}\text { Kontrol negatif (Pemberian pakan } \\ \text { tanpa diberi Vaksin HydroVac). }\end{array} \\ \mathrm{P} 1= & \begin{array}{l}\text { Pemberian Vaksin HydroVac } \\ \text { dengan Dosis } 3 \mathrm{~mL} / \mathrm{Kg} \text { pakan }\end{array} \\ \mathrm{P} 2= & \text { Pemberian Vaksin HydroVac }\end{aligned}$




$$
\mathrm{P} 3=\begin{aligned}
& \text { dengan Dosis } 4 \mathrm{~mL} / \mathrm{Kg} \text { pakan } \\
& \text { Pemberian Vaksin HydroVac } \\
& \text { dengan Dosis } 5 \mathrm{~mL} / \mathrm{Kg} \text { pakan }
\end{aligned}
$$

\subsection{Prosedur Penelitian}

\subsubsection{Persiapan Wadah dan Pakan Uji}

Wadah yang digunakan dalam penelitian ini adalah keramba dengan ukuran $1 \times 1 \times 1$ m sebanyak 12 unit yang terbuat dari jaring, diletakan di Waduk Fakultas Perikanan dan Kelautan Universitas Riau, kemudian dimasukkan ikan mas dengan padat tebar 25 ekor $/ \mathrm{m}^{3}$ (Ananda et al., 2015).

Pakan yang digunakan merupakan pakan komersil jenis PF-999 dengan kandungan protein sebesar 35\%. Vaksin HydroVac berasal dari produk HydroVac, Bogor. Pembuatan pakan dengan cara mengencerkan Vaksin HydroVac ke dalam akuades sebanyak $100 \mathrm{~mL}$ untuk masingmasing perlakuan (3-5 mL). Selanjutnya vaksin disemprotkan ke pakan dengan menggunakan sprayer sedikit demi sedikit sampai merata setelah itu dikering anginkan, dan pakan siap digunakan.

\subsubsection{Pemeliharaan Ikan}

Ikan mas ukuran 8-10 $\mathrm{cm}$ yang berasal dari BBI Sei Tibun Kabupaten Kampar. Ikan mas yang dimasukkan ke dalam keramba dan diaklimatisasi selama satu minggu. Pada awal pemeliharaan ikan dipuasakan selama dua hari. Pemeliharaan dilakukan selama 30 hari dan selama pemeliharaan benih ikan uji diberi pakan yang sesuai dengan taraf perlakuan. Pemberian pakan dilakukan tiga kali sehari, yaitu pada pukul 08.00, 13.00, dan 17.00 WIB sebanyak $10 \%$ dari bobot tubuh. Setiap 10 hari dilakukan pengukuran panjang dan berat untuk mengetahui jumlah pakan yang diberikan pada pemeliharaan selanjutnya.

\subsubsection{Pengambilan Darah Ikan}

Pengambilan darah ikan uji dilakukan sebanyak tiga kali, yaitu pada awal pemeliharaan (H-0) sebelum diberi perlakuan, kedua pada hari ke-15 dan yang ketiga pada hari ke-30. Sebelum pengambilan darah, ikan dibius dalam larutan minyak cengkeh dosis $0,1 \mathrm{ml} / \mathrm{L}$, syringe dan tabung eppendorf dibasahi terlebih dahulu dengan antikoagulan, yaitu EDTA 10\%. Darah ikan diambil dari bagian linea lateralis arah caudal dengan menggunakan syringe $1 \mathrm{~mL}$, darah yang telah diambil dimasukkan ke dalam tabung eppendorf dan selanjutnya digunakan untuk penghitungan total eritrosit, kadar hemoglobin dan kadar hematokrit.

\subsection{Parameter yang Diamati \\ 2.4.1. Total Eritrosit}

Prosedur Darah yang telah diberi EDTA $10 \%$ dihisap dengan pipet haemocytometer (terdapat bulir berwarna merah untuk eritrosit) sampai tanda 0,5. Kemudian ditambahkan larutan hayem (untuk eritrosit) dihisap sampai tanda 101. Agar darah tercampur secara merata, maka pipet digoyang membentuk angka delapan selama 3-5 menit. Sebelum perhitungan eritrosit, darah dalam pipet haemocytometer terlebih dahulu dibuang sebanyak dua tetes untuk menghilangkan rongga udara, lalu darah diteteskan pada kotak haemocytometer dan ditutup dengan cover glass, untuk selanjutnya diamati di bawah mikroskop dengan perbesaran $10 \times 40$. Jumlah total eritrosit dihitung sebanyak 5 kotak kecil pada haemocytometer menurut rumus (Blaxhall dan Daisley, 1973):

$$
\text { Jumlah eritrosit }=\Sigma N X 10^{4} \mathrm{sel} / \mathrm{mm}^{3}:
$$

\subsubsection{Kadar Hemoglobin}

Perhitungan kadar hemoglobin dilakukan dengan mengacu pada metode Sahli. Kadar hemoglobin diukur dengan cara; tabung sahlinometer diisi dengan larutan $\mathrm{HCl}$ $0,1 \mathrm{~N}$ sampai angka 0 (garis skala paling bawah pada tabung sahlinometer), kemudian tabung tersebut ditempatkan di antara 2 tabung dengan warna standar, lalu darah ikan diambil dari tabung microtube dengan pipet Sahli sebanyak $0,02 \mathrm{~mL}$ dan dimasukkan ke tabung Sahli dan didiamkan 3 menit, sebelumnya ujung pipet dibersihkan terlebih dahulu. Kemudian ditambahkan akuades dengan pipet tetes sedikit demi sedikit sambil diaduk dengan gelas pengaduk sampai warnanya tepat sama dengan warna standar. Kadar hemoglobin dinyatakan dalam g/dL (Wedemeyer dan Yasutake, dalam Dosim et al., 2013).

\subsubsection{Kadar Hematokrit}

Sampel darah dimasukkan dalam tabung kapiler hematokrit sampai kira-kira 4/5 bagian tabung, Bagian ujung kapiler ditutup dengan penutup khusus atau dengan 
menggunakan malam (seal), kapiler diletakkan pada sentrifuge (microhematocrit centrifuge). Kemudian tabung mikrohematokrit tersebut disentrifuge selama 5 menit dengan kecepatan 3000 rpm dengan posisi tabung yang bervolume sama berhadapan agar putaran sentrifuge seimbang. Setelah itu diukur persentase dari nilai hematokrit. Kadar hematokrit dinyatakan sebagai \% volume sel darah (Anderson dan Siwicki, 1993). Kemudian nilai hematokrit yang diperoleh dibaca pada alat baca khusus (microhematocrit reader).

\subsubsection{Tingkat Perlindungan Relatif}

Menurut Nitimulyo et al. (2005), tingkat perlindungan relatif dapat dihitung dengan rumus sebagai berikut:

$\mathrm{RPS}=\left[1-\frac{\% \text { kematian ikan divaksin }}{\% \text { kematian ikan yang tidak divaksin }}\right] \mathrm{X} 100 \%$

\subsection{Analisis Data}

Data yang diperoleh dari pengukuran total eritrosit, kadar hemoglobin, kadar hematokrit, pertumbuhan bobot mutlak, tingkat kelulushidupan dan tingkat perlindungan relatif dianalisis dengan menggunakan analisa variansi (ANAVA) dan uji rentang Student Newman-Keuls. Data kualitas air ditabulasikan dalam bentuk tabel, kemudian dianalisis secara deskriptif.

\section{Hasil dan Pembahasan}

\subsection{Total Eritrosit Ikan Mas}

Hasil pengamatan total eritrosit ikan mas yang diberi pakan mengandung vaksin Hydrovac pada hari ke 15 berkisar antara 1,10 - $1,15 \times 10^{6} \mathrm{sel} / \mathrm{mm}^{3}$, sedangkan pada hari ke 30 berkisar antara $2,03-2,12 \times 10^{6} \mathrm{sel} / \mathrm{mm}^{3}$. Hasil analisis variansi (ANAVA) menunjukkan bahwa pemberian pakan mengandung vaksin HydroVac memberikan pengaruh antar perlakuan terhadap total eritrosit ikan mas setelah pemeliharaan selama 30 hari $(\mathrm{P}<0,05)$. Hasil uji lanjut Student Newman-Keuls menunjukkan bahwa setiap perlakuan berbeda nyata. Lebih jelas dapat dilihat pada Tabel 1 .

Tabel 1. Total Eritrosit ikan mas yang diberikan pakan mengandung vaksin HydroVac

\begin{tabular}{|c|c|c|c|}
\hline \multirow{2}{*}{ Perlakuan } & \multicolumn{3}{|c|}{ Total Eritrosit $\left(\mathbf{x 1 0}^{6} \mathrm{sel} / \mathrm{mm}^{3}\right)$} \\
\hline & H-0 (Awal) & H-15 & H-30 \\
\hline PO (kontrol) & $1,06 \pm 0,01$ & $1,09 \pm 0,01^{\mathrm{a}}$ & $1,12 \pm 0,02^{\mathrm{a}}$ \\
\hline P1 (3 mL/kg) & $1,06 \pm 0,01$ & $1,10 \pm 0,02^{\mathrm{ab}}$ & $2,03 \pm 0,02^{\mathrm{b}}$ \\
\hline P2 (4 mL/kg) & $1,06 \pm 0,01$ & $1,12 \pm 0,01^{\mathrm{b}}$ & $2,08 \pm 0,01^{\mathrm{c}}$ \\
\hline P3 (5 mL/kg) & $1,06 \pm 0,01$ & $1,15 \pm 0,01^{\mathrm{c}}$ & $2,12 \pm 0,02^{\mathrm{d}}$ \\
\hline
\end{tabular}

Keterangan : Superscript yang berbeda menunjukkan berbeda nyata $\mathrm{P}<0,05$

Rerata total eritrosit ikan mas pemeliharaan selama 30 hari berkisar antara $1,12-2,12 \times 10^{6} \mathrm{sel} / \mathrm{mm}^{3}$. Nilai total eritrosit yang tertinggi terdapat pada perlakuan $\mathrm{P} 3$ $\left(2,12 \times 10^{6} \mathrm{sel} / \mathrm{mm}^{3}\right)$, sedangkan yang terendah terdapat pada perlakuan P0 $\left(1,12 \times 10^{6}\right.$ $\mathrm{sel} / \mathrm{mm}^{3}$ ). Total eritrosit selama penelitian berada pada kisaran normal. Menurut Syawal et al. (2011), total eritrosit ikan mas berkisar antara $1,026-2,140 \times 10^{6} \mathrm{sel} / \mathrm{mm}^{3}$.

Nilai total eritrosit pada perlakuan yang diberikan vaksin HydroVac memiliki nilai yang lebih tinggi dibandingkan perlakuan tanpa penambahan HydroVac (P0), hal ini disebabkan vaksin HydroVac mampu meningkatkan sel eritrosit dalam darah ikan. Menurut Utami et al. (2013), vaksin HydroVac berperan sebagai immunostimulan yang mampu memperbaiki dan meningkatkan sistem kekebalan tubuh ikan dan masuknya antigen ke dalam tubuh akan memicu terbentuknya respon imun dilihat dari total eritrositnya.

Dosis $5 \mathrm{~mL} / \mathrm{kg}$ pakan (P3) menghasilkan total eritrosit yang lebih tinggi, Jika dibandingkan dengan $\mathrm{P} 1$ ( $3 \mathrm{~mL} / \mathrm{kg}$ pakan) dan P2 (4 mL/kg) yang dosisnya lebih rendah, hal ini menunjukkan bahwa dosis P1 dan P2 belum memberikan respon imunitas yang maksimal. Menurut Bahar et al. (2017), peningkatan dosis vaksin yang diberikan dapat mengubah immunogenitas dan ada dosis tertentu yang dapat menimbulkan respons imunitas yang optimal.

Peningkatan eritrosit ikan mas selama 30 hari pemeliharaan disebabkan beberapa faktor, yaitu umur dan ukuran ikan, serta nutrisi pakan. Faktor-faktor yang mempengaruhi 
jumlah eritrosit adalah spesies, jenis kelamin, umur, nutrisi pakan, ukuran, aktivitas fisik, dan umur (Emu, 2010). Pemanfaatan vaksin Hydrovac melalui perendaman mampu meningkatkan total eritrosit ikan jambal siam berkisar antara $1,89-2,32$ x $10^{6} \mathrm{sel} / \mathrm{mm}^{3}$ (Sinaga et al., 2019). Menurut Siregar (2020), total eritrosit ikan jambal siam yang diberi vaksin Hydrovac pada pakan sebanyak 10 $\mathrm{mL} / \mathrm{kg}$ pakan berkisar antara 1,42-1,66 x $10^{6}$ $\mathrm{sel} / \mathrm{mm}^{3}$. Hal ini menunjukkan bahwa vaksin HydroVac mampu berperan dalam memperbaiki kondisi fisiologis dan kesehatan ikan.

\subsection{Kadar Hemoglobin}

Hasil pengamatan hemoglobin ikan mas yang diberi pakan mengandung vaksin HydroVac pada hari ke 15 berkisar antara $6,53-6,93 \mathrm{~g} / \mathrm{dL}$, sedangkan pada hari ke 30 berkisar antara 7,13 - 7,80 g/dL (Tabel 2).

Tabel 2. Kadar Hemoglobin Ikan mas yang diberikan pakan mengandung vaksin HydroVac

\begin{tabular}{lccc}
\hline \multirow{2}{*}{ Perlakuan } & \multicolumn{3}{c}{ Kadar hemoglobin $(\mathbf{g} / \mathbf{d L})$} \\
\cline { 2 - 4 } & H-0 (awal) & $\mathbf{H - 1 5}$ & $\mathbf{H - 3 0}$ \\
\hline P0 (kontrol) & $5,67 \pm 0,58$ & $6,33 \pm 0,11^{\mathrm{a}}$ & $6,53 \pm 0,11^{\mathrm{a}}$ \\
P1 $(\mathbf{3} \mathbf{~ m l} / \mathbf{k g})$ & $5,67 \pm 0,58$ & $6,53 \pm 0,11^{\mathrm{a}}$ & $7,13 \pm 0,11^{\mathrm{b}}$ \\
P2 $(\mathbf{4} \mathbf{~ m l} / \mathbf{k g})$ & $5,67 \pm 0,58$ & $6,93 \pm 0,11^{\mathrm{b}}$ & $7,80 \pm 0,20^{\mathrm{c}}$ \\
P3 $(\mathbf{5} \mathbf{~ m l} / \mathbf{k g})$ & $5,67 \pm 0,58$ & $7,33 \pm 0,11^{\mathrm{c}}$ & $8,67 \pm 0,31^{\mathrm{d}}$ \\
\hline
\end{tabular}

Keterangan : Superscript yang berbeda menunjukkan berbeda nyata $\mathrm{P}<0,05$

Rerata kadar hemoglobin ikan mas selama 30 hari pemeliharaan berkisar antara 6,53-8,67 g/dL. Kadar hemoglobin yang tertinggi terdapat pada perlakuan P3 $(8,67$ $\mathrm{g} / \mathrm{dL})$, sedangkan terendah pada P0 $(6,53$ $\mathrm{g} / \mathrm{dL})$. Hal ini menunjukkan bahwa pemberian vaksin dengan dosis $5 \mathrm{~mL} / \mathrm{kg}$ pakan (P3) mampu memberikan ketahanan tubuh yang lebih baik dibandingkan perlakuan lainnya, sehingga insang tetap bisa optimal mengikat oksigen di udara dan menjaga nilai hemoglobin pada kisaran normal. Kisaran kadar hemoglobin ikan mas masih berada pada kisaran normal. Menurut Kusrini et al. (2019), kadar hemoglobin ikan mas berkisar antara 4,9-9,65 g/dL.

\subsection{Kadar Hematokrit}

Hasil pengamatan hematokrit ikan mas selama 30 pemeliharaan berkisar antara berkisar antara 26,00-34,33\%. Lebih jelas dapat dilihat pada Tabel 3 .

Tabel 3. Kadar Hematokrit Ikan Mas yang Diberikan Pakan Mengandung Vaksin HydroVac

\begin{tabular}{lccc}
\hline \multirow{2}{*}{ Perlakuan } & \multicolumn{3}{c}{ Kadar Hematokrit (\%) } \\
\cline { 2 - 4 } & H-0 (Awal) & H-15 & H-30 \\
\hline P0 (kontrol) & $22,67 \pm 0,57$ & $24,00 \pm 1,00^{\mathrm{a}}$ & $26,00 \pm 1,00^{\mathrm{a}}$ \\
P1 (3 $\mathbf{~ m l} / \mathbf{k g})$ & $22,67 \pm 0,57$ & $26,00 \pm 1,00^{\mathrm{b}}$ & $27,33 \pm 1,53^{\mathrm{a}}$ \\
P2 (4 ml/kg) & $22,67 \pm 0,57$ & $27,67 \pm 0,58^{\mathrm{c}}$ & $31,00 \pm 1,00^{\mathrm{b}}$ \\
P3 (5 $\mathbf{~ m l} / \mathbf{k g})$ & $22,67 \pm 0,57$ & $28,33 \pm 0,58^{\mathrm{c}}$ & $34,33 \pm 1,53^{\mathrm{c}}$ \\
\hline
\end{tabular}

Keterangan : Superscript yang berbeda menunjukkan berbeda nyata $\mathrm{P}<0,05$

Rerata kadar hematokrit ikan mas 30 hari pemeliharaan berkisar antara 26,00-34,33\%. Kadar hematokrit yang tertinggi terdapat pada perlakuan P3 (34,33\%), Nilai hematokrit tersebut masih berada pada kisaran normal. Peningkatan hematokrit ikan mas menunjukkan bahwa vaksin HydroVac mampu menstimulasi respons dalam peningkatan hematokrit.

Menurut Santika et al. (2009), pemberian vaksin pada ikan cendrung mampu menstimulasi respons dalam bentuk peningkatan kadar hematokrit, peningkatan faktor-faktor seluler darah ini selanjutnya akan menjadi efektor bagi peningkatan respons pertahanan spesifik (antibodi) yang lebih cepat. Shabirah et al. (2019) menyatakan bahwa kadar hematokrit ikan mas berkisar antara $21-44 \%$, sedangkan menurut Soltanian et al. (2018) kadar hematokrit ikan mas normal mencapai $40 \%$.

Peningkatan kadar hematokrit juga dipengaruhi oleh bertambahnya ukuran ikan. Nursatia et al. (2017) menyatakan bahwa nilai 
hematokrit dapat berubah tergantung dari musim, suhu dan pemberian pakan dan dampak pemberian immunostimulan. Nilai hematokrit bervariasi tergantung pada faktor nutrisi, umur ikan, jenis kelamin, ukuran tubuh, dan masa pemijahan. Berdasarkan hasil analisis variansi (ANAVA) menunjukkan bahwa pemberian pakan mengandung vaksin HydroVac dengan dosis berbeda memberikan pengaruh nyata pada setiap perlakuannya terhadap kadar hematokrit ikan mas selama 30 hari pemeliharaan $(\mathrm{P}<0,05)$.

\subsection{Tingkat Perlindungan Relatif}

Tingkat perlindungan relatif ikan mas masing-masing berkisar antara 44,67-61,33\%, dapat dilihat pada Tabel 4.

Tabel 4. Tingkat Perlindungan Relatif Ikan Mas

\begin{tabular}{|c|c|}
\hline Perlakuan & $\begin{array}{l}\text { Tingkat Perlindungan Relatif } \\
(\%)\end{array}$ \\
\hline P0 (kontrol) & \\
\hline P1 $(3 \mathrm{ml} / \mathrm{kg})$ & $44,67 \pm 9,24$ \\
\hline P2 $(4 \mathrm{ml} / \mathrm{kg})$ & $44,67 \pm 9,24$ \\
\hline P3 $(5 \mathrm{ml} / \mathrm{kg})$ & $66,67 \pm 28,87$ \\
\hline
\end{tabular}

Pengamatan tingkat perlindungan relatif ikan mas yang diberi pakan mengandung vaksin HydroVac berkisar antara 44,33$66,67 \%$. Pemberian vaksin HydroVac pada pakan dengan dosis berbeda tidak memberikan pengaruh antar perlakuan $(\mathrm{P}>0,05)$. Hal ini menunjukkan bahwa vaksin HydroVac mampu meningkatkan respons imun ikan mas. Pemberian vaksin dengan dosis $5 \mathrm{~mL} / \mathrm{kg}$ pakan memberikan tingkat perlindungan relatif yang baik. Menurut Kamiso (2001), bahwa kualitas vaksin dianggap baik apabila tingkat perlindungan relatif (RPS) $>50 \%$.

Ikan yang divaksinasi dapat meningkatkan kekebalan pada tubuh ikan sehingga tahan terhadap serangan penyakit selama beberapa waktu. Menurut Ellis (1988) dalam Hidayatullah (2013), metode vaksinasi dapat memperkecil angka kematian, dimana vaksin bertujuan memberikan resistensi individu terhadap penyakit tanpa resiko mengidap penyakit itu sendiri.

\section{Kesimpulan dan Saran}

Kesimpulan Berdasarkan hasil penelitian, maka dapat disimpulkan bahwa ada pengaruh pemberian HydroVac pada pakan terhadap profil darah merah ikan mas yang dipelihara di keramba $(\mathrm{P}<0,05)$. Dosis terbaik pemberian vaksin HydroVac pada pakan yaitu $5 \mathrm{~mL} / \mathrm{kg}$ pakan (P3), dilihat dari gambaran darah merah seperti rata-rata total eritrosit $2,12 \times 10^{6}$ $\mathrm{sel} / \mathrm{mm}^{3}$, hemoglobin $8,67 \mathrm{~g} / \mathrm{dL}$, kadar hematokrit $34,33 \%$, dan tingkat perlindungan relatif $66,67 \%$.

Berdasarkan penelitian yang telah dilaksanakan, vaksin A.hydrophila dapat diaplikasikan melalui pakan dengan dosis 5 $\mathrm{mL} / \mathrm{kg}$. Selanjutnya dapat dilakukan penelitian lanjutan mengenai pemberian vaksin A.hydrophila melalui penyuntikan (injeksi).

\section{Daftar Pustaka}

Anderson, D.P., and A.K. Siwicki. (1993). Basic Haemotology and Serology for Fish Health Programs. Paper Presented in Second Symposium on Disease in Asian Aquaculture. Aquatic Animal Health and The Environment. Phuket, Thailand. 25-29 Oktober 1993. $17 \mathrm{hlm}$

Andriyanto, S. dan D. Sugiani. (2015). Performa Pertumbuhan Benih Ikan Lele (Clarias gariepinus) dengan Aplikasi Vaksin HydroVac. Media Akuakultur, 10(2): 59-64

Blaxhall and K.W. Daisley. (1973). Routine Haematological Methods for use with Fish Blood. Journal of Fish Biology, 5: $577-581$.

Citarasu, T., A. Dhas, S. Velmurugan, T. Viji, T. Kumaran, M. Babu, and T. Selvaraj. (2011). Isolation of Aeromonas hydrophila from Infected Ornamental Fish Hatchery during Massive Disease Outbreak. Int. J. Curr. Res: 037-041.

Dosim, E. Hardi, dan Agustina. (2013). Efek Penginjeksian Produk Intraseluler (ICP) dan Ekstraseluler (ECP) Bakteri Pseudomonas sp. terhadap Gambaran Darah Ikan Nila (Oreocromis niloticus). Jurnal Ilmu Perikanan Tropis, 19(1):24-13.

Emu, S. (2010). Pemanfaatan Garam pada Pengangkutan Sistem Tertutup Benih Ikan Patin (Pangasius sp) Berkepadatan Tinggi dalam Media yang Mengandung Zeolit dan Arang Aktif. Tesis. Sekolah Pascasarjana. Institut Pertanian Bogor. Bogor. $80 \mathrm{hlm}$

FAO. (2019). Fisheries and Aquaculture Information and Statistic 
Branchcommon Carp, Cyprinus carpio. Rome: Italy. $90 \mathrm{hlm}$

Hidayatullah, D. (2013). Efikasi Vaksin dengan Metode Infiltrasi Hiperosmotik untuk Pencegahan Infeksi Bakteri Streptococcus agalactiae pada Ikan Nilai. Skripsi. Fakultas Perikanan dan Ilmu Kelautan. Institut Pertanian Bogor. $45 \mathrm{hlm}$.

Kamiso, N.H. (2001). Imunologi dan Vaksinasi pada Ikan. Diskusi Vaksinasi dan Imunologi Ikan. DUE Project. Fakultas Perikanan Universitas Riau. Pekanbaru. 1-8 hlm.

Kusrini, E., S. Nuryati, S. Zubaidah, dan L. Sholihah. (2019). Pemberian Vaksin DNA Anti-KHV Ikan Mas dengan Dosis Berbeda terhadap Benih Ikan Koi. Jurnal Riset Akuakultur, 14(2): 95108

Lusiastuti, A.M., dan W. Hadie. (2010). Penggunaan Vaksin Aeromonas hydrophila: Pengaruhnya terhadap Sintasan dan Imunitas Larva Ikan Patin. Berita Biologi, 10(2) : 151-158

Mailani, D., Olga, Fatmawati, dan N.A. Fauzana. (2020). Vaksin Bivalen Aeromonas hydrophila untuk Meningkatkan Ketahanan Tubuh Ikan Patin Siam (Pangasius hypophthalmus) terhadap Serangan Motile Aeromonas Septicemia. Jurnal Perikanan dan Kelautan, 10(1): 43-54

Maryani dan Rosita. (2006). Efektivitas Ekstrak Daun Biji Efektivitas Ekstrak Daun Jambu Biji (Psidium guajava L.), Sambiloto (Andrographis paniculata), dan Daun Sirih (Piper Betle L) dalam Menanggulangi Infeksi Bakteri Aeromonas hydrophila pada Ikan Mas (Cyprinus Carpio). Journal of Tropical Fisheries, 1 (2):132-139.

Mohd-Aris A, Muhamad-Sofie MHN, Zamri SM, Daud HM, Ina-Salwany MdY. (2019). Live Vaciines Against Bacterial Fish Diseases: A review, Veterinary World 12(11):1806-1815.DOI: www.doi.org/10.14202/vetworld.2019. 18006-1815

Mulia, D.S. (2007). Keefektifan Vaksin Aeromonas hydrophila untuk Mengendalikan Penyakit MAS (Motile Aeromonas Septicemia) pada Gurami
(Osphronemus Gouramy Lac.). Jurnal Pembangunan Pedesaan, 7(1): 43-52 (2012). Penggunaan Vaksin Debris sel Aeromonas hydrophila dengan inverval Waktu Booster Berbeda terhadap Respons Imun Lele Dumbo (Clarias gariepinus Burchell). Journal Sains Aquatic, 10(2): 86-95

Nitimulyo, K.H., A. Isnansetyo, dan Triyanto. (2005). Efektivitas Vaksin Polivalen untuk Pengendalian Vibriosis pada Kerapu Tikus (Cromileptes altivelis). Jurnal Perikanan, 7(2): 95-100

Nursatia., Sarjito dan A.H.C. Haditomo. (2017). Pemberian Ekstrak Bawang Putih dalam Pakan sebagai Imunostimulan terhadap Kelulushidupan dan Profil Darah Ikan Patin (Pangasius sp). Journal of Aquaculture Management and Technology 6(3) : 234-241.

Santika, A., Ciptoroso, Z. Zainun, Sumarjo, dan Suroso. (2009). Peningkatan Daya Tahan Tubuh Ikan Mas Terhadap Infeksi Koi Herpes Virus (KHV) Melalui Teknik Vaksinasi (Uji Lapang). Laporan Tinjauan Hasil BBPBAT. Sukabumi. 134-148.

Shabirah, A., Rosidah, Y. Mulyani, dan W. Lili. (2019). Effect of Types Isolated Lactic Acid Bacteria on Hematocrit and Differential Leukocytes Fingerling Common Carp (Cyprinus carpio L.) Infected with Aeromonas hydrophila bacteria. WNOFNS, 24: 22-35

Sinaga, R., M. Riauwaty, dan H. Syawal. (2019). Hematologycal of Jambal siam (Pangasius hypophthalmus) That Using Aeromonas hydrophila Vaccine. Jurnal Online Mahasiswa Fakultas Perikanan dan Ilmu Kelautan, 6: 1-15

Siregar, M., M. Riauwaty, dan I. Lukistyowati. (2020). Jumlah Sel Darah Merah Ikan Jambal Siam (Pangasius hypophthalmus) yang Diberi Pakan Mengandung Vaksin Hydrovac. JOM Faperika, 7(2): 1-13

Sumiati, T., Taukhid, dan A.M. Lusiastuti. (2019). Evaluasi Standar Kualitas Vaksin Hydrovac Untuk Pencegahan Penyakit Motile Aeomonads Septicemia (Mas) Pada Ikan Lele Afrika (Clarias sp.). Media Akuakultur, 14(1): 41-47 
Syawal, H., N. Kusumorini, W. Manalu dan R. Affandi. (2011). Respon Fisiologis dan Hematologis Ikan Mas (Cyprinus carpio) pada Suhu Media Pemeliharaan yang Berbeda. Jurnal Iktiologi Indonesia, 12(1): 1-11.

Taukhid., L. Gardenia, dan S. Andriyanto. (2016). Efikasi Vaksin Kombinasi "Trivalen" (Aeromonas hydrophila, Streptococcus agalactiae, dan Mycobacterium fortuitum) untuk Pencegahan Penyakit Bakteri Potensial pada Budidaya Ikan Air Tawar. Jurnal Riset Akuakultur, 11(4): 373-385

Taukhid., U. Purwaningsih, D. Sugiani, T. Sumiati, dan A.M. Lusiastuti. (2015). Efikasi Vaksin In-Aktif Bakteri Aeromonas hydrophila-AHL0905-2 (HydroVac) dan Streptococcus agalactiae-N14G (StreptoVac) untuk Pencegahan Penyakit Bakterial pada Ikan Budidaya Air Tawar. Jurnal Riset Akuakultur, 10 (4): 541-551
Utami, D.T., S.B. Prayitno., S. Hastuti., A. Santika. (2013). Gambaran Parameter Hematologis pada ikan Nila (Oreochromis niloticus) yang Diberi Vaksin DNA Steprococus iniae dengan Dosis yang Berbeda. Journal of Aquaculture Management and Tecnology, 2(4) : 7-20

Zhang, X., W. Yang, H. Wu, X. Gong, and A. Li. (2017). Multilocus sequence typing revealed a clonal lineage of Aeromonas hydrophila caused motile Aeromonas septicemia outbreaks in pond cultured cyprinid fish in an epidemic area in central China. Aquaculture, 432: 1-6. 